\title{
Research on the Development of Teachers' Morality and Style in Colleges and Universities
}

\author{
Lun $\mathrm{Li}^{1} \quad \mathrm{Jia} \mathrm{Liu}^{2}$ Correspondence \\ (1. Human Resources Department, Central University of Finance and Economics, Beijing, China, 100081 \\ 2. Graduate School, Central University of Finance and Economics, Beijing, China, 100081)
}

\begin{abstract}
In the new higher education environment, there are still some problems in teachers' morality and style, such as the lack of long-term mechanism, the lack of comprehensive evaluation system, and the lack of effective internal supervision mechanism. This paper tries to solve the problems in developing teachers' morality and style in colleges and universities.
\end{abstract}

Keywords: higher education; colleges and universities; teachers' morality and style

DOI : $10.36012 /$ fhe. v2i2. 2769

\section{The importance of research on the construc-} tion of teachers morality and style in Colleges and Universities

1. 1 The development of teachers' morality and style is of great importance to the development of higher education teachers

As an important foundation for the development of world-class universities and disciplines, the evaluation of teachers' team development should be measured from five aspects: teachers' overall level, teachers' scientific research achievements, teachers' teaching ability, teachers' academic reputation and teachers' social contribution (Chu Hongsheng, 2016). Except for the scientific research achievements and teaching ability of university teachers, their professional morality and teaching style can meet the requirements of "double first-class" also has great meaning of building world-class universities and first-class disciplines. In the process of promoting the "double first-class" development, colleges and universities should strengthen the de- velopment of teachers' morality and conduct, cultivate an excellent teaching team with ideals and beliefs, moral sentiment, solid knowledge, and benevolence.

However, in the process of promoting the "double first - class" development in colleges and universities, there are specific and clear guidance programs and relevant measures for the development of teaching staff and disciplines. However, only some principled documents have been issued for the corresponding development of teachers' morality, which is difficult to promote the development of teachers' morality and style. In the process of building "double first-class", excellent teachers' morality and style are the source power of the development of colleges and universities, and also one of the fundamental guarantees for the steady development of teaching and educating people in colleges and universities. Pursuing academic first - class, discipline first - class without the development of first-class morality and style of teachers will inevitably lead to teachers' misunderstand- 
ing of the responsibility and mission of teachers. Therefore, the theoretical research on teachers morality and style in colleges and universities in the new era is of great significance to the development strategy of "double first-class" in colleges and universities.

\section{2 The theoretical research on the development of} teachers' morality and style in colleges and universities is of great guiding significance to cultural heritage

University culture, as the accumulation of various spiritual qualities of a university for a long time, reflects the core ideas, ideas and other spiritual elements of a university. As the main body of running a university, the teachers' morality and style is the core of a university's cultural development, and the teachers' morality and style can better reflect the cultural quality of a university. Teachers are a group that can best represent the spirit of a university and the most direct creator, embodiment, and guardian of university culture. An excellent university needs excellent university culture. The decisive factor of this kind of university culture is the teacher's morality, and its core is the university spirit. The character of teachers can best reflect the spirit of the university and influence the formation of the university culture. Mr.

Mei Yiqi, former President of Tsinghua University, has a famous saying: "The so-called university is not that there are buildings, but there are masters." This sentence reflects the role of teachers in the development of universities, such as the supporting role of reinforced concrete to the building. Excellent teachers' morality is not only the embodiment of university culture spirit but also the premise of university development. Teachers' morality of an era essentially reflects the cultural spirit of an era. As an academic highland, universities lead the spiritual direction of the times. The spiritual connotation of teachers' morality repre- sents the spiritual pursuit of universities and the cultural essence of universities. (Zhang Shasha, 2011)

On one hand, the development of university teachers' morality requires teachers, as the executors of social responsibility, to establish morality and cultivate people, to fulfill the glorious social mission; on the other hand, as the main body of civil morality, university teachers' moral cultivation is also a measure of whether they can achieve the standards of learning to be a teacher and behaving in a world (Zhang Chuang, 2016). Only by strengthening the development of teachers' morality and style, can colleges and universities fulfill and undertake their due social responsibilities. Therefore, the theoretical research on the development of teachers' morality in colleges and universities in the new era is of far - reaching significance to improve the moral level of the whole nation.

\section{3 Strengthening the development of teachers' mo-} rality and style is the need of improving the overall level of teachers

At all times and in all countries, being a teacher is one of the oldest professions in human history, and has always been regarded as one of the greatest and most sacred professions. The greatness and holiness of the teacher's profession, in addition to knowledge teaching, is more reflected in the noble teacher's morality and style. A great man pointed out: "people's teachers are supreme glory". "Teachers are engineers of human souls and inheritors of human civilization. They carry the important task of disseminating knowledge, disseminating ideas, spreading the truth, shaping souls, shaping life and shaping new people." The professional characteristics of teachers determine that teachers must be moral people. Only when they are aware of great morality, abide by public morality and be strict with private morality, and transform objective moral principles into their moral i- 
deals, moral cultivation and moral behavior, can we better cultivate, infect students, and better form the social fashion of the great morality, public morality and private morality that we advocate in the whole society to be inherited (Wang Jihong, $2020)$.

Whether a teacher has noble moral sentiment and a strong sense of career and responsibility directly affects the quality of education and teaching. In this sense, setting an example and being a teacher's model is a minimum requirement for teachers' professional activities and a necessary moral quality for teachers' profession. Therefore, teachers must strengthen their self - cultivation and exert a subtle influence on students with noble morality, profound knowledge, and good quality. Teachers' morality and style are closely related to teachers' ideological and moral quality, work attitude, professional level, and working principles and are vividly reflected through teachers' teaching, scientific research, and other work. However, with the change of the distribution pattern of material interests, people's values tend to be diversified. Moral imbalance is eroding the body of teachers who should be noble (Song Dongying, 2009).

\section{Problems in the development of teachers morality and style in colleges and universities}

2. 1 The long - term mechanism of the development and management of teachers morality in colleges and universities is still not complete

At present, some colleges and universities have established the Management Committee of Teachers' Morality and Conduct, and on this basis, formulated the management system of teachers' morality and style in colleges and universities according to the relevant requirements. However, the improvement of the system does not mean that colleges and universities have a complete mechanism for the development of teachers' morality and style. The development of teachers' morality in some colleges and universities is still at the level of shouting slogans, and the specific implementation of relevant systems still lacks effective mechanism. For example, the relevant documents issued by universities on the official account of WeChat's public address and micro-blog platform have limited influence on teachers and students in colleges and universities. This kind of practice lacks specific measures for the development of teachers' morality and style, so it isn't easy to implement the relevant system of teachers' morality and the relevant requirements of internal teachers' morality in colleges and universities. Therefore, colleges and universities should establish a complete set of a long - term mechanism for the management and operation of teachers morality development according to relevant systems.

\section{2 There is still a lack of objective, fair and effec-} tive evaluation standards for teachers' morality and style in Colleges and universities

The evaluation standard of university teachers morality and style plays an important role in the development of teachers' morality. Facing the new problems in the new era, colleges and universities should formulate comprehensive and effective evaluation standards in line with the current objective situation. However, most colleges and universities have not carried out in-depth research in this area and still use the traditional way to measure teachers' morality and style according to the standard of satisfaction of teachers and students, simply according to the survey form and assessment form. Firstly, this traditional way cannot objectively reflect the specific situation of teachers' morality and style, and it is difficult to understand the actual situation of teachers in teaching, scientific research, life, and other aspects; secondly, this traditional way lacks professionalism, ordinary teachers and students lack professional morality and 
teachers' style screening ability, often without indepth understanding, according to their relationship with the evaluated teachers; thirdly, the traditional evaluation results are too simple to play the role of supervision and improvement of teachers' morality.

\section{3 The function of internal supervision and im-} provement in colleges and universities is insufficient, and there are still a few college teachers who seriously violate the requirements of teachers' morality and style

The development of teachers' morality and style in colleges and universities has been steadily promoted, and a series of effective achievements have been made. However, there are still a small number of university teachers who, for various reasons, have made a variety of acts contrary to the requirements of the development of university teachers' morality. At present, all kinds of new media based on the Internet have become one of the important channels for information dissemination and information acquisition. The specific cases about the problems of university teachers' morality have been widely reported through WeChat, Micro Blog, QQ, and other new media for many times, which has seriously damaged the image of university teachers and hindered the continuous and stable advancement of the development of university teachers' morality.

In addition, a few college teachers are not enterprising and perfunctory in their work. With the rapid development of the Internet technology, the spread of knowledge has gone beyond the physical space of the classroom and free flow, the creation of learning has gone beyond national boundaries and rapid growth, and the knowledge reserve of $\mathrm{u}^{-}$ niversity teachers has been far from keeping up with the development of academic frontiers. In the face of knowledge explosion, teachers' self-confidence in studying and tracking intellectual bounda- ries is insufficient, especially a few have obtained teachers with professional titles are satisfied with their academic identity and are no longer willing to continue to explore and research. They have relaxed the requirements of self - discipline (Song Dongxia, 2020).

\section{Countermeasures for problems of the devel-} opment of teachers' morality and style in colleges and universities

3. 1 Improve the long-term mechanism of the development of teachers' morality and style according to relevant systems

Colleges and universities should promote the normalization and long - term development of teachers morality and conduct, formulate various specific measures according to the relevant system of teachers' morality, and set up particular supervision institutions to ensure the implementation of specific measures. In the multiple links of teacher's entry examination, pre-job training, daily teaching, scientific research, professional and technical post evaluation, rank promotion and excellent recommendation, specific measures related to teacher' s morality and style should be set up to make the development of teacher's morality run through the whole process of teacher's development. At the same time, in the specific development of teachers' morality and style, colleges and universities should regularly use the new media to summarize and publicize the internal work so that the public can understand the dynamics of the universities ' development of teachers' morality and conduct, and use this channel to let the society supervise the specific work of the school and discuss the specific measures and behaviors of the university (Wang Nan, 2019).

\section{2 Establish a set of objective, fair and effective} comprehensive evaluation system for teachers' morality and style

In the design of the evaluation system of teachers' 
morality and style in colleges and universities, we should take the scientific principle as the principle, update the design concept in time, take the new idea as the guide, improve the setting of evaluation indicators, and ensure the relevance of the evaluation system. The scientific setting of the evaluation system can provide a unified standard for the corresponding evaluation personnel of teachers morality and style, help to improve the professionalism of the evaluators, and make the evaluation criteria not too single. A fair and reasonable evaluation system can effectively avoid the subjective evaluation of evaluators in the evaluation process and ensure the objectivity of evaluators in the evaluation process. Even teachers who are strict in teaching life will not be subject to low malicious evaluation, which is not only conducive to ensuring the teaching enthusiasm of more strict teachers but also helps to ensure the fairness of the evaluation mechanism. The principle of fairness minimizes the interference of human factors (Zhang Xiaokai, 2019).

\section{3 Establishing the supervision mechanism for the} development of teachers' morality and style

Colleges and universities have set up a working group for the development of teachers' morality with the participation of the principal heads of various departments. It is responsible for the investigation, inspection, and evaluation of teachers' morality and the planning, organization, and implementation of other activities of teachers' morality education, as well as the education of teachers' professional ideal, professional morality and professional discipline together with relevant departments. Set up the supervision group of teachers' morality development, mainly to understand the teachers' thoughts, work and living conditions, and combine the problems of teachers' morality with solving the actual difficulties and problems of teachers. At the same time, we can also make full use of modern information resources and encourage students to evaluate teachers' morality and conduct through various means and channels such as online evaluation of teaching affairs office, so as to urge teachers to update their ideas and improve their moral cultivation (Hong Ting, 2010).

In addition to the above - mentioned internal supervision mechanism, the personnel department and petition department of colleges and universities should also establish an effective external supervision mechanism. First of all, the personnel department should check from the source. For every teacher introduced by the school, they should strictly carry out the entrance examination, go deep into the graduate school or the original unit, visit their teachers and leaders, and fully understand the basic personal situation; secondly, the personnel department and the petition section can establish special complaint channels and make them public to the society through the network, media, and other channels; finally, the personnel department should set up a special management department to summarize the problems existing in the society and carry out special inspection and supervision regularly.

\section{4 It is necessary to strengthen the self-discipline} consciousness of teachers in colleges and universities.

First of all, we should guide college teachers to establish correct world view, life view and values view, carry out relevant training and convey an idea, that is, first learn to behave, and then go to be a teacher. For a long time, some college teachers mistakenly believe that their duties are to impart professional knowledge and carry out scientific research. Do not include teaching students "learn to behave" into the training objectives and responsibilities, which will undoubtedly affect the overall development of students. Therefore, in the process of teaching and educating people, teachers should use their own "moral conduct" to influence 
students, guide students, teach them how to behave, and cultivate students' noble sentiments. Secondly, to guide college teachers to need both speech teaching" and "personal education", they should constantly strengthen their political theory study and constantly update their own business knowledge structure. As the transmitter of human culture, they should have more and more extensive knowledge base than the educated, read more and think, update the educational and teaching concepts in time, stand at the forefront of the times, and ask students to learn new knowledge Before, I master and master it. Third, we should guide college teachers to cultivate and educate students with new and healthy thinking. When facing their students, they should take the lead in the behavior they advocate and truly achieve "their integrity, not to let them go" (Zhao Peiju, 2013).

\section{Conclusion}

To sum up, in the context of the new era of education environment, colleges and universities should pay attention to the development of teachers' morality and style, because this work has an important guiding significance for the development of $\mathrm{u}^{-}$ niversity teachers, the development and inheritance of university culture, the shaping of teachers' style and the improvement of teachers' quality. At present, we should realize that the long - term mechanism of the development and management of teachers' morality and style in colleges and universities is still not complete, there is still a lack of objective, fair and effective evaluation standards for teachers' morality and style, the internal supervision and improvement function of colleges and $\mathrm{u}^{-}$ niversities are insufficient, and there are still a few college teachers' behaviors seriously violating the requirements of teachers' morality and style. Therefore, we should take effective measures to improve the long-term mechanism of the develop- ment of teachers' morality and conduct, establish a set of objective, fair and effective comprehensive evaluation system for teachers' morality, establish a supervision mechanism for the development of teachers' morality, and strengthen the self-discipline consciousness of college teachers to be upright and exemplary.

\section{Reference}

[1] Chu Hongsheng, Wang Yunhai. Research on the development path of university teaching staff under the background of "double first class" $[\mathrm{J}]$. Beijing Education, 2016 (11)

[2] Zhang Shasha. Consumption behavior and guidance of contemporary college students [D]. Nanjing Normal University, 2011

[3] Zhang Chuang. Strengthening the development of teachers' morality and style to create a first - class teaching staff $[\mathrm{J}]$. Beijing Education, 2016 (05)

[4] Wang Jihong. Realistic challenges and optimization strategies for the development of teachers' morality and style in colleges and universities in the new era $[\mathrm{J}]$. Theory of Ideological Education, 2020 (05)

[5] Song Dongying. On the development of College Teachers' style and Morality under the new situation [J]. China Science and Technology Information, 2009 (23)

[6] Song Dongxia. Reflection on strengthening the development of teachers' morality and style in colleges and universities $[\mathrm{J}]$. Beijing Education, 2020 (05)

[7] Wang Nan. Problems and Countermeasures of teachers' morality development under the new media environment $[\mathrm{J}]$. Regional Governance, 2019 (44)

[8] Zhang Xiaokai. Analysis on the index design of the $\mathrm{e}^{-}$ valuation system of teachers' morality and style in colleges and universities in the new era $[\mathrm{J}]$. Science and Education, 2019 (09)

[9] Hong Ting. Problems and Countermeasures in the development of teachers' Morality in Colleges and universities [J]. Journal of Inner Mongolia Normal University (Education Science Edition), 2010 (09)

[10] Zhao Peiju. Strengthening the development of teachers' morality and style, cultivating high-quality teachers $[\mathrm{J}]$. China Higher Education, 2013 (13) 